\title{
Effects Of Problem-Solving Method On Secondary School Students' Achievement And Retention In Social Studies, In Ekiti State, Nigeria
}

B.O. Abdu-Raheem, University of Ado-Ekiti, Nigeria

\begin{abstract}
This study investigated the effects of problem-solving method of teaching on secondary school students' achievement and retention in Social Studies. The study adopted the quasi-experimental, pre-test, post-test, control group design. The sample for the study consisted of 240 Junior Secondary School Class II students randomly selected from six secondary schools in Ekiti State, Nigeria. The instrument used for the study is the Social Studies Achievement Test (SSAT) designed and validated by the researcher. Section A of the instrument consisted of the bio-data of the respondents while section $B$ was made up of 40 multiple-choice items designed to measure the students' achievement and retention in Social Studies. Four hypotheses were raised and tested at 0.05 level of significance. The data were analyzed using $t$-test and ANCOVA statistical tools. The results showed that there is a significant difference between the achievement mean scores of students in the experimental and control groups. There is a significant difference between the pretest mean scores and achievement mean scores of students in the experimental and control groups. There is a significant difference between the retention mean scores of students in the experimental and control groups. There is a significant difference between the achievement mean scores and the retention mean scores of students in the experimental and control groups. It was discovered in the study that problem-solving method is more effective than conventional lecture method in improving students' achievement in Social Studies. It was therefore recommended that teachers should be innovative in handling their lessons by relating them to the day-to-day life of students in such a way that the students will be challenged to put the lessons to practice as much as possible. Government should also emphasize the use of problem-solving method to teach Social Studies in secondary schools.
\end{abstract}

Keywords: Effects; Problem-Solving; Secondary School; Students; Academic Achievement; Ekiti State; Nigeria

\section{INTRODUCTION}

$\mathrm{t}$ is a matter of grave concern for educational stake-holders that the level of achievement and commitment of students to learning is reducing day-in-day-out. One of the major causes identified is the ineffective teaching of the school subjects including Social Studies. It was also noted that most of the students of nowadays are very lazy and too playful. They can hardly identify and solve problems that come their ways by themselves. They mostly rely on parents, teachers and elders to solve problems for them. May be during teaching/learning processes, teachers have not been giving them challenging tasks that could enhance development of thinking skills and creative activities. It is therefore the focus of this paper to investigate the relative effects of problem-solving method on students' achievement and retention in Social Studies.

Social Studies, as the study of human beings in their physical, social, economic, spiritual, scientific, political, cultural and psychological environment, needs to be taught effectively (Fadeiye, 2005). However, problem-solving as a method of teaching that gives room for interaction with materials, asking of questions and 
criticism of issues should also arouse interests in and enhance basic understanding of the subject. Obebe (1981) and Adewuya (1989) carried out different researches on the knowledge of contents and teaching methods in Social Studies in Teacher Training Colleges and Secondary Schools in Ekiti state respectively. They discovered that lecture method had negative effects on students. Such effects include lack of motivation, inability to cover the contents of the curriculum, negative attitudes towards the subject and low achievement on the part of the teachers and students.

Ipaye (1991) stated that conventional lecture method is not effective in achieving the aims of teaching Social Studies. Ipaye (1991) arrived at the conclusion that performance of Nigerian students in West African School Certificate Examinations (WASCE) had been progressively bad. He therefore, suggested that professional teachers should experiment with new methods of teaching to stem the tide of poor performance in examinations. Adewuya (2003) also established the fact that the rate of absorption in secondary schools is as low as 20 to $30 \%$ as a result of lecture method used to teach in schools. Abdu-Raheem (2010) also concluded that lecture method is ineffective in teaching Social Studies in secondary schools in Ekiti State, Nigeria.

Problem-solving involves techniques such as questioning, sorting, field trips, interviewing, brainstorming, role-playing, projects, use of resource persons, library search and other creative activities (Adewuya 2003). All these techniques open up students to problem-solving activities such as critical thinking, searching for more knowledge, analyzing, investigating and collating issues and ideas, formulating hypotheses, experimenting guesses and collecting and analyzing information (Adewuya, 2002).

According to Joyce, Well and Calhoun (2000), inquiry/problem-solving is a learning process whereby questions are created or problems are developed by the students based on facts and observations examined logically. Iyamu and Otote (2007) confirmed that inquiry/problem-solving is a whole complex of instructional phenomenon in which the teacher makes use of a variety of methods and activities that encourage students' active involvement in the generation of their own knowledge. Craig (2001) defined a problem as any situation where one has an opportunity to make a difference or to make things better. Problem solving is converting the actual current situation into a desired future situation. He explained further that the acts of creative and critical thinking about ways to increase the quality of life or avoid a decrease in quality are acts of problem solving.

Problem-solving approach to teaching usually involves an interest approach, a description of teaching objectives, identification of the problems to be solved, actual problem solution, testing of the solution and an evaluation of the solution (Newcomb, McCracken, Warmbrod \& Whittington, 2004). Mann (2001) also agreed that it is essential to develop awareness in the students that they themselves have the reason why a solution is not being found to a particular problem. He pointed out that if the teacher moves from a problem towards a solution, the students will be in the dark until the last moment. Ayeni (2007) reported that problem-solving approach is used to identify particular issues and raises questions on them, hypothesizing possibilities and seeking evidence to establish facts in educational research.

In support of the above ideas, Hermann (2007) recommended brainstorming or mind-storming at the first stage of problem-solving, even before defining the problem. He explained further that brainstorming requires using the creative hemisphere of one's brain before the logical hemisphere takes over. Mistry, White \& Berardi (2006) concluded that the area of problem-solving skills is considered a high priority skill area, even in post-graduate studies development.

Herrman (2007) equated preference dominance to creative problem-solving. He believed that dominance or cognitive thinking processes or preferred modes of knowing have advantages in quick response time and higher skills level. Douglas and Kristin (2000) agreed that students can learn both new concepts and skills while solving problems. Jimoh (2001) also supported the idea that problem-solving method develops students' interest in critical thinking and evaluative reasoning. Abdu-Raheem (2010) concluded that if the steps required in the use of problemsolving method of teaching such as identification of problem, observation, interpretation, manipulation and creativity, are properly utilized, students' achievement will increase drastically.

Orimogunje (2008) emphasized the need for using an innovative strategy such as problem-solving to correct the mismatch of post-primary Social Studies with the traditional lecture method. In support of the above 
idea, Bandele (2003) confirmed that the health of classroom interaction is dictated by the quality of instructions given during the actual lesson periods. Sotonwa (2003) explained that good teaching matters in raising the standard of education and the achievement of students. Ekanola (2007) concluded that problem-solving is designed to facilitate both knowledge acquisition and utilization.

Akinleye (2010) observed that children are known to be effective problem-solvers and decision makers when given the opportunity to be listened to and guided in a non-threatening atmosphere. Akinleye (2010) also noted that pupils must be put on the right part of problem-solving with understanding and insight. Seweje (2010) noted that in learning generally, learners must interact with contents in order to construct their own meanings so as to integrate new knowledge into the existing cognitive structure. Seweje (2010) recommended that steps should be taken to improve the overall teaching, practical and service delivery and equally charged the teachers to make the subject interesting and friendly.

\section{STATEMENT OF THE PROBLEM}

Observation shows that many teachers still rely heavily on the traditional lecture method of teaching Social Studies in Nigerian Secondary Schools. It has also been noted that the poor academic performance of most of the students is imputed largely to the conventional lecture method used for teaching them. This paper therefore attempts to investigate the effects of problem-solving on students' achievement in Social Studies.

\section{RESEARCH HYPOTHESES}

In an attempt to find solutions to the problem raised, the following hypotheses were formulated:

1. There is no significant difference between the achievement mean scores of students in the experimental and control groups.

2. There is no significant difference between the retention mean scores of students in the experimental and control groups.

3. There is no significant difference between the pre-test mean scores and the achievement mean scores of students in the experimental and control groups.

4. There is no significant difference between the achievement mean scores and the retention mean scores of students in the experimental and control groups.

\section{METHODOLOGY}

The study adopted quasi-experimental, pre-test, post-test, control group, design. The population for this study comprised all Junior Secondary School students in Ekiti State with the total number of 14,867 students. The sample consisted of 240 Junior Secondary School Class II students of Social Studies from six schools. Simple random sampling was adopted to select 40 students from six schools used for the study. Simple random sampling was also used to allocate the groups into experimental and control groups. The instrument for the study is the Social Studies Achievement Test (SSAT) designed by the researcher. The instrument consisted of 40 multiple-choice items used for pre-test, post-test and retention test on students sampled. The validity of the instrument was ascertained through face, content and construct validity procedures. The instrument was given to two test experts in Guidance and Counseling, two in Educational Management and two specialists in Social Studies. They were requested to find the face value and the appropriateness of the instrument in measuring the students' achievement and retention in Social Studies. The reliability of the instrument was ascertained through test-re-test method and estimation of internal consistency. The instrument was administered on 40 students from two schools that were not used for the study. After two weeks, the instrument was administered again on the same sets of students. The responses of the two sets of students were correlated using Pearson Product Moment Correlation Coefficient Analysis and the correlation coefficient of 0.73 was obtained. Crombach Alpha was also applied on the responses of 30 students from a school that was not used for the study for the estimation of internal consistency. The formula when applied yielded the reliability coefficient of 0.71 which is good enough to measure the differences between experimental and control groups when large samples are used. 
The instrument was first administered on students by exposing all of them to pre-test to test their knowledge baseline in Social Studies. The students were randomly assigned to experimental and control groups. The experimental group was then exposed to treatment for six weeks while the control group was going on with their normal classroom conventional lecture method. The instrument was also administered on the experimental and control groups, to test their level of achievement. After six weeks, the instrument was administered again on both experimental and control groups to test their level of retention. The data collected were analyzed using students' ttest, and ANCOVA statistical tools.

\section{RESULTS AND DISCUSSION}

\section{Hypothesis 1}

There is no significant difference between the achievement mean scores of students in the experimental and control groups.

Table 1: ANCOVA Summary of Achievement Mean Scores of students in the Experimental and Control Groups

\begin{tabular}{|l|c|c|c|c|c|}
\hline \multicolumn{1}{|c|}{ Source } & SS & Df & MS & F-cal & F-table \\
\hline Corrected Model & 31244.892 & 2 & 15622.446 & 1338.387 & 3.00 \\
\hline Covariate (pre-test) & 259.354 & 1 & 259.354 & 22.219 & 3.84 \\
\hline Group & 30978.815 & 2 & 30978.815 & 2653.979 & 3.84 \\
\hline Error & 2766.404 & 237 & 11.673 & & \\
\hline Corrected Model & 34011.296 & 239 & & & \\
\hline Total & 159001.000 & 240 & & & \\
\hline
\end{tabular}

$\mathrm{P}<0.05$

Table 1 shows that F-cal (2653.979) is greater than F-table (3.84) at 0.05 level of significance. The null hypothesis is rejected. Therefore, there is a significant difference between the achievement mean scores of students in the experimental and control groups.

In order to provide some indications of the performances of the groups, a Multiple Classification Analysis (MCA) was computed as shown in Table 2 below.

Table 2: Multiple Classification Analysis Showing

the Effects of Treatment on Students' Achievement Scores in Social Studies

\begin{tabular}{|l|c|c|c|c|c|}
\hline \multicolumn{1}{|c|}{ Grand Mean = 25.57 } \\
\hline Variable + Category & $\mathbf{N}$ & $\begin{array}{c}\text { Unadjusted } \\
\text { Deviation }\end{array}$ & Eta & $\begin{array}{c}\text { Adjusted For Independent + } \\
\text { Covariate }\end{array}$ & Beta \\
\hline Experimental & 120 & 8.61 & 0.30 & -14.09 & 0.03 \\
\hline Control & 120 & -14.11 & & 0.088 \\
Multiple R & \multicolumn{5}{|c|}{0.088} \\
\hline
\end{tabular}

Table 2 reveals that students in the experiment group had higher adjusted post-test mean score of 34.20 $(25.57+8.63)$ while those not exposed obtained an adjusted post-test mean score of $14.48[25.57+(-14.09)]$ in Social Studies Achievement Test. The observed difference in the adjusted post-test mean scores of students in Social Studies portrays the potency of the treatment employed at producing better achievement of students $\mathrm{n}$ Social Studies.

\section{Hypothesis 2}

There is no significant difference between the retention mean scores of students in each of the experimental and control groups. 
Table 3: t-test of Retention Mean Scores of Students in the Experimental and Control Groups

\begin{tabular}{|l|c|c|c|c|c|c|}
\hline \multicolumn{1}{|c|}{ Group } & $\mathbf{N}$ & Mean & SD & Df & t-cal & t-table \\
\cline { 1 - 4 } Experimental & 120 & 32.71 & 3.26 & \multirow{2}{*}{238} & 63.336 & 1.960 \\
\hline
\end{tabular}

$\mathrm{P}<0.05$

Table 3 reveals that $t$-cal (63.336) is greater than t-table (1.960) at 0.05 level of significance. The null hypothesis is rejected. Therefore, there is a significant difference between the retention mean scores of students in the experimental and control groups.

\section{Hypothesis 3}

There is no significant difference between the pre-test mean scores and achievement mean scores of students in each of the experimental and control groups.

Table 4: t-test Showing the Pre-test and Achievement Mean Scores of Students in the Experimental and Control Groups

\begin{tabular}{|l|l|c|c|c|c|c|c|}
\hline \multicolumn{1}{|c|}{ Group } & \multicolumn{1}{|c|}{ Variable } & N & Mean & SD & Df & t-cal & t-table \\
\hline \multirow{2}{*}{ Experimental } & Pre-test & 120 & 9.28 & 3.43 & \multirow{2}{*}{5} & \multirow{2}{*}{54.398} \\
& Achievement & 120 & 34.18 & 3.41 & & \\
\multirow{2}{*}{ Control } & Pre-test & 120 & 9.27 & 3.67 & & 7.353 & 1.98 \\
& Achievement & 120 & 11.46 & 3.71 & & \\
\hline
\end{tabular}

$\mathrm{P}<0.05$

Table 4 reveals that $\mathrm{t}$-cal (Experimental $=54.398$, Control) is greater than t-table $(1.98)$ at 0.05 level of significance. The null hypothesis is rejected. Therefore, there is a significant difference between the pre-test mean scores and the achievement mean scores of students in each of the experimental and control groups.

\section{Hypothesis 4}

There is no significant difference between the achievement mean scores and the retention mean scores of students in each of the experimental and control groups.

Table 5: t-test Showing the Achievement and Retention Mean Scores of Students in the Experimental and Control Groups

\begin{tabular}{|c|c|c|c|c|c|c|c|}
\hline Group & Variable & $\mathbf{N}$ & Mean & SD & df & t-cal & t-table \\
\hline Experimental & $\begin{array}{l}\text { Achievement } \\
\text { Retention }\end{array}$ & $\begin{array}{l}120 \\
120\end{array}$ & $\begin{array}{l}34.18 \\
32.71\end{array}$ & $\begin{array}{l}3.41 \\
3.26\end{array}$ & 119 & 4.379 & 1.98 \\
\hline Control & $\begin{array}{l}\text { Achievement } \\
\text { Retention }\end{array}$ & $\begin{array}{l}120 \\
120\end{array}$ & $\begin{array}{l}11.46 \\
7.66 \\
\end{array}$ & $\begin{array}{l}3.71 \\
2.85 \\
\end{array}$ & 119 & 14.409 & 1.98 \\
\hline
\end{tabular}

$\mathrm{p}<0.05$

Table 5 shows that $\mathrm{t}$-cal $($ Experimental $=4.379$, Control $=14.409)$ is greater than $\mathrm{t}$-table $(1.98)$ at 0.05 level of significance in each case. Therefore, the null hypothesis is rejected. It implies that there is a significant difference between the achievement mean scores and the retention mean scores of students in each of the experimental and control groups. 


\section{DISCUSSION}

The result of this study revealed that the achievement level of students in Social Studies was generally low at the initial stage, but the level of achievement improved drastically and significantly in the experimental group (problem-solving) after the treatment. There was also an improvement on the achievement level of students in the control group, but not so significant. Adewuya (2003) submitted that the problems are likely to be solved with the contribution of knowledge and ideas from several knowledgeable people to tackle greater problems beyond the simple information.

The study also revealed that problem-solving method of teaching Social Studies is highly effective. The improvement in the level of achievement of students in the experimental group was as a result of the treatment (problem-solving method). This is in line with the submission of UNESCO (1984) that the problem-solving method seems to be more effective than the traditional expository method bringing about learning, relation, transfer, stimulating thinking in learners and, as a result, more active students' participation is encouraged in the classroom.

It was shown in this study that there is a significant difference between the retention mean scores of students in the experimental and control groups. The retention mean scores of students in the experimental group is higher than those students in the control group as a result of problem-solving method used to give treatment to the students in the experimental group. The finding is related to that of Orimogunje (2008) who emphasized the need for using an innovative strategy such as problem-solving to correct the mismatch of post-primary Social Studies with the traditional lecture method. Abdu-Raheem (2010) also agreed that problem-solving has the best potency to improve the students' achievement in Social Studies.

\section{CONCLUSION}

It is hereby concluded in this study that problem-solving method is more effective than conventional lecture method in improving students' achievement in Social Studies and that the use of the problem-solving method is the solution to the dwindling performance of students in Social Studies.

\section{RECOMMENDATIONS}

Based on the findings, it was recommended that:

1. Government should emphasize the use of problem-solving to teach Social Studies in secondary schools.

2. Government should also organize on-the-job training, workshops, seminars and conferences for teachers of Social Studies on effective use of problem solving method of teaching.

3. Teachers should change from the conventional lecture method to the problem-solving method of teaching Social Studies.

\section{AUTHOR INFORMATION}

Dr. (Mrs.) Bilqees Olayinka Abdu-Raheem, is a lecturer in the Department of Educational Foundations and Management, Faculty of Education, University of Ado-Ekiti, Nigeria. Her area of research is Social Studies and Educational Management. She has attended many learned conferences and presented papers of which some have been published locally and internationally. She is a member of the National Association of Women in Academics [NAWACS]. Her e-mail address is dr_boabduraheem@yahoo.com

\section{REFERENCES}

1. Abdu-Raheem, B. O. (2010) Relative effects of problem-solving and discussion methods on secondary school students' achievement in social studies. Unpublished Ph.D thesis, University of Ado-Ekiti, AdoEkiti, Nigeria. 
2. Adewuya, S.A. (1989) "Effectiveness of the problem-approach in the teaching and learning of selected topics in social studies in junior secondary schools in Ondo State". Unpublished Ph.D Thesis, Obafemi Awolowo University, Ile-Ife, Nigeria.

3. Adewuya, S.A. (2002) "Principles and concept of social studies". Ado-Ekiti: Yemi Publishing Co.Ltd.

4. $\quad$ Adewuya, S.A. (2003) Social science methods, Ado-Ekiti: Green Line Publishers.

5. Akinleye, G.A. (2010) Enhancing the quality of life in this complicated but dynamic world, $25^{\text {th }}$ Inaugural Lecture, University of Ado-Ekiti, Ado-Ekiti, $6^{\text {th }}$ April, 2010.

6. Ayeni, J.O. (2007) Philosophy and education research: A conceptual clarification. Journal of Educational Foundations and Management. 5(1) 73-84.

7. Bandele, S. O. (2003). "The universal basic education in perspective: need for formative evaluation". Nigerian Journal of Educational Research and Evaluation. (4)1, 54-58.

8. Craig, R. (2001) Thinking skills \& problem-solving methods in education. http://www.asa3.org/ASA/education/think/methods.htm. retrieved on 10/06/2009.

9. Douglas, A.G. \& Kristin, J.C. (2000). Improving students achievement in mathematics. International Academy of Education (IAE). 1211 Geneva 20, Switzerland. http://www.unesco.org or http://www.curtin.edu.au/curtin/dept/smec/iae. retrieved on 10/06/2009.

10. Ekanola, A.Y. (2007) Enhancing problem-solving and mathematical skills in the junior secondary schools. Being lecture delivered at $4^{\text {th }}$ quarter capacity building workshops for teachers organised by Ekiti State SUBEB.

11. Fadeiye, J.O. (2005). A social studies textbook for colleges and university. Ibadan: Akin-Johnson Press \& Publishers.

12. Herrmann, N. (2007) Dominance, or cognitive: Wikipedia details, http://en.wikipedia.org/wiki/HerrmannBrain-Dominance-Instrument(accessed:9/3/07).

13. Ipaye, B. (1991). "Reception of school by teachers and students influence on teaching and learning outcome". International yearbook on teacher education. Lagos: Nigeria, International Council of Education for Teaching World Assembly.

14. Iyamu, E.O.S. \& Otote, C.D. (2007) "Assessment of inquiry teaching competencies of social studies teachers in junior secondary schools in south Nigeria" in S. Adejuwon social studies teaching methods need to be changed. The Punch, Jan. 5.32

15. Jimoh, S.A. (2001). "Providing quality education in the new millenium. Problems and prospects". Being the text of the lecture delivered at the $13^{\text {th }}$ Convocation Ceremony of the Federal College of Education (Special), Oyo.

16. Joyce, B. Well, M. \& Calhoun, E. (2000) Models of teaching (sixth edition), Boston: Atlyn \& Bacon.

17. Mann, D. (2001) The space between 'generic' and 'specific' problem solution. The TRIZ Journal, http://www.triz-journal.com/archives/2001/06/c/index.htm. retrieved on 10/08/2009.

18. Mistry, J., White, F. \& Berardi, A. (2006) Skills at Masters' level in geography higher education: teaching, learning and applying, planet, 16. The Higher Education Academy: Gees.

19. Newcomb, McCracken, Warmbrod, \& Whittington. (2004). Methods of teaching agriculture (third edition). Upper Saddle River: http://www.thefreelibrary.com/The+problem-solving+approach-a0173643504.

20. Obebe, B.J. (1981) "An assessment of knowledge of social studies content and method of graduating elementary teachers (Grade II) of Lagos and Ondo State, Nigeria". An unpublished Ph.D. Dissertation, Teachers' College, Columbia University, New York.

21. Orimogunje, T. (2008) "Effects of two problem-solving models in facilitating students' learning outcomes in chemistry". Journal of Educational Foundations and Management. 6(1) 228-234.

22. Seweje, R.O. (2010) Defining issues in science education. $24^{\text {th }}$ Inaugural Lecture, University of Ado-Ekiti, Ado-Ekiti. $8^{\text {th }}$ March, 2010.

23. Sotonwa, O.O. (2003) "Quality teacher and quality teaching towards achieving quality in Universal Basic Education". Nigerian Journal of Educational Research and Evaluation. (4)1, 69-78.

24. UNESCO, (1984). Teaching methodologies in population education: Inquiry/discovery approach and values clarification. Bangkok, Thailand: Regional Office for Education in Asia and the Pacific. 


\section{NOTES}

